\title{
PHYTO-BASED PRESERVATION OF RAW SKINS FOR SALINITY REDUCTION IN TANNERY WASTEWATER
}

\section{CONSERVAREA PIEILOR CRUDE CU AJUTORUL PLANTELOR PENTRU REDUCEREA SALINITĂTII APELOR REZIDUALE DIN TĂBĂCĂRII}

\author{
Marudhamuthu VINODHKUMAR ${ }^{1 *}$, Velappan BRINDHA ${ }^{2}$, James KANAGARAJ ${ }^{2}$, Alagumuthu TAMILSELVI $^{1}$, Sayeed SADULLA $^{3}$ \\ ${ }^{1}$ Centre for Human and Organizational Resources Development (CHORD), CSIR-CLRI, Chennai, India, vinodh14579@gmail.com \\ ${ }^{2}$ Leather Process Technology Division, CSIR-CLRI \\ ${ }^{3}$ Indian Leather Products Association, Chennai, India
}

PHYTO-BASED PRESERVATION OF RAW SKINS FOR SALINITY REDUCTION IN TANNERY WASTEWATER

ABSTRACT. Leather industry is one of the top polluting industries albeit producing precious commodities for human use. Curing of raw skins and hides with salt is one chief deterrent increasing the Total Dissolved Solids (TDS) of water bodies and fertile lands. In this present investigation, an attempt has been made to reduce the salt used for preservation by substituting with plant extracts. Plants like Cassia fistula Linn. (Cassia), family Caesalpiniaceae and Psidium guajava L, family Myrtaceae display brilliant antimicrobial qualities. Experimental skin (goat) samples were treated with $5 \%$ Salt + 5\% Cassia paste, 10\% Salt + 10\% Cassia paste, 15\% Salt $+15 \%$ Cassia paste, $5 \%$ salt $+5 \%$ Guava paste, $10 \%$ salt $+10 \%$ Guava paste, $15 \%$ salt $+15 \%$ Guava paste and $40 \%$ salt according to the skin weights respectively . The experimental skins were preserved for 21 days and were observed for hair slip, smell and putrefaction. Estimation of protein, hydroxyproline and moisture content and microbial load were tested on the $1^{\text {st }}, 2^{\text {nd }}, 3^{\text {rd }}, 7^{\text {th }}, 14^{\text {th }}$ and $21^{\text {st }}$ day. On the $21^{\text {st }}$ day the skins were processed into leather and their physical properties were examined and found comparable to the conventionally cured skins. Hence, this cleaner curing method helps in reducing the TDS in the effluent, thus controlling pollution caused by tanneries through salt.

KEY WORDS: phyto-based preservation, Cassia fistula, Psidium guajava, wastewater, salinity reduction.

CONSERVAREA PIEILOR CRUDE CU AJUTORUL PLANTELOR PENTRU REDUCEREA SALINITĂTII APELOR REZIDUALE DIN TĂBĂCĂRII

REZUMAT. Industria de pielărie este una dintre industriile cele mai poluante, deşi este producătoare de materii prime preţioase pentru uz uman. Conservarea pieilor crude cu sare este poluantă, conducând la creşterea substanţelor solubile totale (TDS) din apă şi terenuri fertile. În cadrul prezentei investigaţii, s-a încercat reducerea sării utilizate pentru conservare prin substituirea acesteia cu extracte din plante. Plante precum Cassia fistula Linn. (Cassia), familia Caesalpiniaceae şi Psidium guajava L, familia Myrtaceae prezintă calităţi antimicrobiene extraordinare. Probele experimentale de piele (capră) au fost tratate cu $5 \%$ sare $+5 \%$ pastă de cassia, $10 \%$ sare $+10 \%$ pastă de cassia, $15 \%$ sare $+15 \%$ pastă de cassia, $5 \%$ sare $+5 \%$ pastă de guava, $10 \%$ sare $+10 \%$ pasta de guava, $15 \%$ sare $+15 \%$ pastă de guava, respectiv cu $40 \%$ sare, în funcţie de greutatea pielii. Pieile experimentale s-au conservat timp de 21 de zile şi au fost evaluate cu privire la căderea părului, miros şi putrefacţie. S-au determinat conţinutul de proteine, de hidroxiprolină şi de umiditate şi încărcătura microbiană în zilele 1, 2, 3, 7, 14 şi 21. În ziua 21, pieile au fost prelucrate până la stadiul de piele finită şi s-au testat proprietăţile fizice, considerându-se comparabile cu pieile conservate în mod convenţional. Prin urmare, această metodă ecologică de conservare ajută la reducerea TDS din efluenţi, controlând astfel poluarea cauzată de tăbăcării prin utilizarea sării.

CUVINTE CHEIE: conservare pe bază de plante, Cassia fistula, Psidium guajava, ape reziduale, reducerea salinităţii.

\section{LA CONSERVATION DES PEAUX À BASE DE PLANTES POUR RÉDUIRE LA SALINITÉ DES EAUX USÉES DES TANNERIES}

RÉSUMÉ. L'industrie du cuir est l'une des industries plus polluantes même si elle produit des matières premières précieuses pour l'usage humain. La conservation des peaux brutes au sel est un processus polluant qui augmente le total des solides dissous (TDS) dans l'eau et les terres fertiles. Dans la présente investigation, on a fait une tentative de réduire le sel utilisé pour la conservation en le substituant aux extraits de plantes. Des plantes comme Cassia fistula Linn. (Cassia), famille Caesalpiniaceae et Psidium guajava L, famille Myrtaceae ont des qualités antimicrobiennes extraordinaires. Les échantillons de peau expérimentale (chèvre) ont été traités avec $5 \%$ sel + 5\% pâte de Cassia, $10 \%$ sel + 10\% pâte de Cassia, $15 \%$ sel + 15\% pâte de Cassia, $5 \%$ sel + 5\% pâte de goyave, $10 \%$ sel + 10\% pâte de goyave, $15 \%$ sel $+15 \%$ pâte de goyave et avec $40 \%$ sel en fonction du poids de la peau brute, respectivement. Les peaux expérimentales ont été conservées pendant 21 jours et ont été analysées pour déterminer le glissement des cheveux, l'odeur et la putréfaction. On a déterminé la teneur en protéine, hydroxyproline et humidité et la charge microbienne le $1^{\mathrm{er}}, 2^{\mathrm{e}}, 3^{\mathrm{e}}, 7^{\mathrm{e}}, 14^{\mathrm{e}}$ et $21^{\mathrm{e}}$ jour. Le $21^{\mathrm{e}}$ jour les peaux ont été transformées en cuir et leurs propriétés physiques ont été examinés et jugés comparables aux peaux classiquement conservées. Par conséquent, ce procédé écologique de conservation contribue à réduire le TDS dans l'effluent, contrôlant ainsi la pollution causée par les tanneries en utilisant le sel.

MOTS CLÉS: conservation à base de plantes, Cassia fistula, Psidium guajava, eaux usées, réduction de la salinité.

* Correspondence to: Vinodhkumar MARUDHAMUTHU, Centre for Human and Organizational Resources Development, CSIR-CLRI, Sardar Patel Road, Adyar, Chennai, India 600020; vinodh14579@gmail.com; +91-9840249513 


\section{INTRODUCTION}

Converting raw hides and skins into leather is ancient. Since the last century, this traditional craftoriented act has transformed into a huge industrialized and profit-making business. In transformation of hides and skins into leather, the hides and skins undergo a temporary and reversible "curing" or "preservation" method to increase the shelf life of these raw materials. Thus, curing, though not one of the essential steps/stages in leather making, has become the foremost and important link in the supply chain. Normally salt is used for preservation purposes though there are many preservation methods, both practiced as well as of academic curiosity. Salt has been identified as a pollutant. Chloride concentration in conventional tannery wastewater is about $9 \mathrm{gl}^{-1}$ which represents a considerable problem for biological plants [1]. Along with the pros, this concentrate act brought in its own cons. Given the current scenario, this industry is ailing through solid and liquid waste management issues. Especially the methods the industry adopts for short term preservation of skins and hides seem easy, but bring in serious disposal problems.

There are different methods adopted in the preservation of skins for a long duration by physical methods (sun drying, controlled drying, cooling and chilling, cooled air treatment, addition of ice and use of dry ice [2]) and in chemical methods, sodium chloride is used at the level of $40-50 \%$ and is the most popular curing method [2]. The short term preservation this industry is adopting leads to serious Total Dissolved Solids (TDS) concerns [3]. This chemical method accounts to about $40 \%$ of chlorides and $55 \%$ of TDS, in the entire leather processing operations [4]. Govindasamy [5] in his study has reported that the effluents from chrome tanning industry should meet with the specific tolerance limits for chloride with $1000 \mathrm{mg} \mathrm{I}^{-1}$, Biological Oxygen Demand (BOD) with $30 \mathrm{mg} \mathrm{I}^{-1}$. Vlyssides [6] mentions the acceptable range for chlorides $\left(\mathrm{mg} \mathrm{l}^{-1}\right)$ as 1500-28000 composition of tannery waste liquors. The common salt based preservation chiefly accounts for the chlorides emanating in the liquid effluents of leather manufacture. The impact of salinity emanating from

\section{INTRODUCERE}

Transformarea pieilor crude în piei finite este o îndeletnicire foarte veche. Începând cu ultimul secol, acest proces tradiţional artizanal s-a transformat într-o imensă afacere industrializată şi aducătoare de profit. La transformarea pieilor crude în piele finită, pieile sunt supuse unei metode temporare şi reversibile de "tratare" sau ",conservare" pentru a prelungi durata de depozitare a acestor materii prime. Astfel, deşi nu se numără printre etapele esenţiale în procesul de fabricare a pielii, a devenit cel mai important element din cadrul lanţului de aprovizionare. În mod normal, se utilizează sarea pentru conservare, deşi există mai multe metode de conservare, atât practicate, cât şi teoretice. Sarea a fost identificată ca substanţă poluantă. Concentraţia de cloruri în apele uzate din tăbăcăriile convenţionale este de aproximativ 9 $\mathrm{gl}^{-1}$, ceea ce reprezintă o problemă considerabilă pentru plante [1]. Pe lângă avantaje, această operaţiune prezintă şi dezavantaje. Având în vedere scenariul actual, această industrie se confruntă cu probleme de gestionare a deşeurilor solide şi lichide. În special metodele pe care le adoptă industria pentru conservarea pe termen scurt a pieilor par simple, dar aduc probleme serioase privind eliminarea deşeurilor.

S-au adoptat diferite metode de conservare a pieilor pentru o durată lungă, prin proceduri fizice (uscarea la soare, uscarea controlată, răcirea, tratarea cu aer rece, adăugarea de gheaţă şi utilizarea zăpezii carbonice [2]) şi proceduri chimice, dintre care utilizarea clorurii de sodiu la nivel de $40-50 \%$ este cea mai des utilizată metodă de conservare [2]. Metodele de conservare pe termen scurt pe care le adoptă această industrie conduc la probleme privind substanţele solubile totale (TDS) [3]. Acestei metode chimice îi revin aproximativ $40 \%$ din cloruri şi $55 \%$ din TDS, din totalul operaţiunilor de prelucrare a pieilor [4]. Govindasamy [5] a raportat în studiul său că efluenţii din procesul tăbăcire cu crom trebuie să se încadreze în limitele de toleranţă specifice pentru clorură, de până la $1000 \mathrm{mg} \mathrm{l}^{-1}$, iar pentru consumul biochimic de oxigen (CBO), de până la $30 \mathrm{mg} \mathrm{l}^{-1}$. Vlyssides [6] menţionează intervalul acceptabil pentru cloruri $\left(\mathrm{mg} \mathrm{l}^{-1}\right)$ între 150028000, din compoziţia apelor reziduale din tăbăcării. Conservarea uzuală pe bază de sare este principala responsabilă pentru clorurile conţinute în efluenţii de la fabricarea pielii. Impactul salinităţii din tăbăcărie 
tannery environment to the ecosystem has been reviewed by Sayeed Sadulla [7] in his article.

Haydar et al. [8] have tried reducing the impurities from the effluent and the percentage removal efficiency for turbidity, Total Suspended Solids (TSS), Chemical Oxygen Demand (COD) and chromium was found to be 98.7-99.8, 94.3-97.1, 53.360.9, and 98.9-99.7\%, respectively. These impurities can be abated only by eliminating the causative from the root itself and adopting a greener means like moving towards eco-friendly method of preservation where the TDS, BOD, COD can be controlled without any additional treatment methods. Research is underway to substitute or minimize the salt used in curing process globally. Phyto-based preservation is one of such attempts adopting an eco-friendly approach. Plants are rich in a wide variety of secondary metabolites such as tannins, terpenoids, alkaloids, flavonoids, glycosides etc., that have antimicrobial properties $[9,10]$ which are indispensable properties for any preservant, temporary or permanent. The plants so far discovered to have curing property are Neem [11], Acalypha indica [12], Weddilia chininsis, Cassia alata, Clerodendron phlomides, Solanum trilobatum, Calotropis procera [13], Semecarpus anacardium nut extract [14].

In the present study, Cassia fistula and Psidium guajava are complemented with the salt curing. Cassia fistula or Indian Laburnum belongs to the family Caesalpiniaceae [15]. Tzakou and his colleagues [16] identified forty-four chemical compounds and the other phytochemicals reported to be present in the leaves of $C$. fistula and they are Anthraquinones like Rhein glucoside, Rhein, Fistulic acid, Sennoside A \& B, Chrysophanol and Physcion, 9-epiafzelechin, 3-O-B-D-Glucopyranoside, 7bioflavonoids and two Triflavonoids together with Epiafzelechin and Procyanidin B-2 [17-19]. The young and old leaves of the plant contain the highest amount of Phenolic, Flavonoid and Proanthocyanidin contents [20]. Leaves and flowers contain Anthraquinone, Tannin, Oxyanthraquinone, Rhein and Volatile oils [21]. Cassia fistula is found to be an effective antibacterial agent against Escherichia coli, Bacillus mycoides, Bacillus subtilis, Mycobacterium smegmatis, Klebsiella aerogenes, Pseudomonas aeruginosa, Proteus vulgaris and $S$. aureus and antifungal against Microsporum asupra ecosistemului a fost analizat de Sayeed Sadulla [7], în articolul său.

Haydar şi colab. [8] au încercat să reducă impurităţile din efluenţi, iar eficienţa de îndepărtare procentuală pentru turbiditate, substanţe solide în suspensie totale (TSS), consumul chimic de oxigen (CCO) şi crom s-a dovedit a fi 98,7-99,8, 94,3-97,1, 53,360,9 şi respectiv $98,9-99,7 \%$. Aceste impurităţi pot fi reduse numai prin eliminarea cauzelor şi prin adoptarea unor mijloace mai ecologice, cum ar fi trecerea la metoda ecologică de conservare prin intermediul căreia TDS, CBO, CCO pot fi controlate fără metode de tratare suplimentare. Se desfăşoară cercetări la nivel global pentru a înlocui sau minimiza sarea utilizată în procesul de conservare. Conservarea pe bază de plante este una dintre aceste încercări de a adopta o abordare ecologică. Plantele au un conţinut bogat de metaboliţi secundari de largă varietate, cum ar fi taninuri, terpenoide, alcaloizi, flavonoide, glicozide, etc., care au proprietăţi antimicrobiene [9, 10], proprietăţi indispensabile pentru orice tip de conservant, temporar sau permanent. Plantele cu proprietăţi de conservare descoperite până în prezent sunt arborele de Neem [11], Acalypha indica [12], Weddilia chininsis, Cassia alata, Clerodendron phlomides, Solanum trilobatum, Calotropis procera [13], extract de nuci Semecarpus anacardium [14].

În studiul de faţă, s-au utilizat Cassia fistula şi Psidium guajava în combinaţie cu metoda conservării cu sare. Cassia fistula sau salcâmul indian aparţine familiei Caesalpiniaceae [15]. Tzakou şi colab. [16] au identificat patruzeci şi patru de compuşi chimici şi alte fitochimicale prezente în frunzele de $C$. fistula şi sunt antrachinone precum glucozida de reină, reina, acidul fistulic, senozida A \& B, crisofanolul şi fisciona, 9epiafzelechina, 3-OBD-glucopiranozida, 7bioflavonoidele şi două triflavonoide împreună cu epiafzelechina şi procianidina B-2 [17-19]. Frunzele tinere şi vechi ale plantei conţin cea mai mare cantitate de fenoli, flavonoide şi proantocianidină [20]. Frunzele şi florile conţin antrachinonă, tanin, oxiantrachinonă, reină şi uleiuri volatile [21]. Cassia fistula se dovedeşte a fi un agent antibacterian eficient împotriva Escherichia coli, Bacillus mycoides, Bacillus subtilis, Mycobacterium smegmatis, Klebsiella aerogenes, Pseudomonas aeruginosa, Proteus vulgaris şi S. aureus şi antifungic, cu acţiune împotriva Microsporum 
gypseum, Trichophyton rubrum and Penicillium marneffei [22-24]. Many pharmacological studies have demonstrated the antioxidant, hepatoprotection, antiallergy, antimicrobial, antigenotoxic, cytotoxic, cardioactive, anticough, antidiabetic and antirheumatic effect of $P$. guajava $[25,26]$.

The main objective of this investigation is to study the curing properties of "Phyto-extract" of Cassia fistula and Psidium guajava leaves after the application on freshly flayed goat skins. The reduced use of common salt and the resultant mileage in disposal of the liquor effluent are relevant gains with respect to this eco-friendly intervention. The experimental skins were studied for 21 days. Afterwards, the leathers made out of the preserved skins were tested for their physical properties and colour characteristics.

\section{MATERIALS AND METHODS}

\section{Collection of Plant Materials}

The leaves of Cassia fistula and Psidium guajava were collected from Adyar, Chennai, India. Then the washed leaves were shade-dried and ground to powder ( $2 \mathrm{~mm}$ mesh). The powder was stored in a brown bottle for future use.

\section{Preparation of Solvent Extract}

Ethanol, Hexane and distilled water extracts were prepared from $5 \mathrm{~g}$ of ground plant leaves (Cassia fistula and Psidium guajava) by suspending them in $25 \mathrm{ml}$ of solvents (Ethanol, Hexane and distilled water respectively) in a shaker for $72 \mathrm{hrs}$. Then, the respective extracts were filtrated with Whatmann filter paper No 1 and evaporated using rotary evaporator [27]. The obtained extracts were stored at $4^{\circ} \mathrm{C}$ for further analysis.

\section{Antimicrobial Assay of Phyto-extract on Isolated Microbes}

Screening of antibacterial potential of the prepared extracts against Bacillus sp., Klebsiella sp. and Proteus sp. were performed by agar well diffusion method according to NCCLS Guidelines [28] in MHA (Mueller Hinton Agar) plates. gypseum, Trichophyton rubrum şi Penicillium marneffei [22-24]. Multe studii farmacologice au demonstrat efectele antioxidante, hepatoprotectoare, antialergice, antimicrobiene, antigenotoxice, citotoxice, cardioactive, anti-tuse, antidiabetice şi anti-reumatice ale $P$. guajava $[25,26]$.

Obiectivul principal al acestei investigaţii este de a studia proprietăţile curative ale extractelor de frunze de Cassia fistula şi Psidium guajava după aplicarea acestora pe piei de capră proaspăt jupuite. Utilizarea redusă a sării comune şi conţinutul care rezultă la eliminarea efluentului lichid sunt avantajele relevante ale acestei intervenţii ecologice. Pieile experimentale au fost studiate timp de 21 de zile. Ulterior, pieile finite prelucrate din pieile conservate au fost testate pentru a determina proprietăţile fizice şi caracteristicile de culoare ale acestora.

\section{MATERIALE ŞI METODE}

\section{Colectarea materialului vegetal}

Frunzele de Cassia fistula şi Psidium guajava au fost colectate din Adyar, Chennai, India. Frunzele spălate au fost uscate la umbră şi măcinate până la obţinerea unei pulberi (sită de $2 \mathrm{~mm}$ ). Pulberea a fost depozitată într-o sticlă de culoare brună pentru utilizare ulterioară.

\section{Prepararea extractului cu solvent}

S-au preparat extracte apoase în etanol, hexan şi apă distilată din $5 \mathrm{~g}$ de frunze de plante măcinate (Cassia fistula şi Psidium guajava) prin suspensia acestora în $25 \mathrm{ml}$ de solvent (etanol, hexan, respectiv, apă distilată) într-un agitator, timp de 72 de ore. Apoi, extractele respective au fost filtrate prin hârtie de filtru Whatmann nr. 1 şi s-a evaporat apa cu ajutorul evaporatorului rotativ [27]. Extractele obţinute au fost depozitate la $4^{\circ} \mathrm{C}$ pentru analize ulterioare.

\section{Testul antimicrobian al extractelor vegetale asupra microbilor izolaţi}

S-a determinat potenţialul antibacterian al extractelor preparate contra Bacillus sp., Klebsiella sp. şi Proteus sp. prin metoda difuzimetrică cu godeuri în agar în conformitate cu liniile directoare NCCLS [29] în plăci MHA (agar Mueller Hinton). 


\section{Test Microorganisms}

The collagen degrading bacteria (Bacillus sps., Klesbeilla sps. and Proteus sps.) isolated from goat skins were selected for testing antimicrobial activity of Cassia fistula and Psidium guajava extracts. Fresh cultures were maintained as nutrient agar slants in screw-capped bottles and stored at $4^{\circ} \mathrm{C}$. All cultures were checked for viability and purity by regular plating and biochemical tests. Test cultures were prepared by transferring a loop full of bacteria from the stock culture to nutrient broth and incubated at $37^{\circ} \mathrm{C}$ for 24 hrs.

\section{Antibacterial Activity (Well Diffusion Method)}

The anti-bacterial activity of the Ethanol, Hexane and distilled water extracts of Cassia fistula and Psidium guajava were tested against Bacillus sps., Klebsiella sps. and Proteus sps. by Agar well diffusion method. The agar-well diffusion method has been used to determine the effect of extracts on bacterial species in vitro. At first, the suspensions (with standard turbidity compared to that of the McFarland standard of 0.5 ) of each of the test bacteria; i.e., Bacillus sps., Klebsiella sps. and Proteus sps. were spread evenly over sterile MHA plates. Wells were then made on the seeded MHA plates by means of sterile cork-borer. Each of the samples was then introduced separately in a concentration of $100 \mu \mathrm{l}$ with a residual herbal medicine concentration. Presence of clear zone around the sample (if any) was analyzed for the existence of the antibacterial activity of the samples after incubation of the plates for 24 hrs. The diameter of the inhibition zone was measured in $\mathrm{mm}$ and recorded.

\section{Application in Leather Industry}

\section{Skin Curing}

Freshly flayed 5 goat skins were obtained from a local slaughter house and each skin was cut into four quarters. In each of the quarter section of the skin, combination of Cassia fistula leaves paste + salt and Psidium guajava leaves paste + salt were applied. The Table 1 explains the experimental design for the study. All the curing materials were applied on the flesh side of the skins based on the raw green weight of the skins.

\section{Microorganisme pentru testare}

Bacteriile care degradează colagenul (Bacillus sp., Klesbeilla sp. şi Proteus sp.) izolate din pieile de capră au fost selectate pentru testarea activităţii antimicrobiene a extractelor de Cassia fistula şi Psidium guajava. Culturile proaspete s-au menţinut în medii nutritive în flacoane cu capac cu filet şi depozitate la $4^{\circ} \mathrm{C}$. Viabilitatea şi puritatea tuturor culturilor au fost verificate prin placare regulată şi teste biochimice. Culturile de testat au fost preparate prin transferarea unei anse bacteriologice din cultura stoc în mediul nutritiv şi au fost incubate la $37^{\circ} \mathrm{C}$ timp de 24 ore.

\section{Activitatea antibacteriană (metoda difuzimetrică cu godeuri)}

Activitatea antibacteriană a extractelor în etanol, hexan şi apă distilată ale Cassia fistula şi Psidium guajava a fost testată împotriva Bacillus sp., Klebsiella sp. şi Proteus sp. prin metoda difuzimetrică cu godeuri în agar. Metoda difuzimetrică cu godeuri în agar a fost utilizată pentru a determina efectul extractelor asupra speciilor bacteriene in vitro. Mai întâi, suspensiile (cu turbiditate standard, comparativ cu cea a standardului McFarland de 0,5$)$ fiecărei bacterii testate, şi anume, Bacillus sp., Klebsiella sp. şi Proteus sp., au fost repartizate în mod egal în plăci sterile MHA. S-au făcut apoi godeuri pe plăcile însămânţate cu ajutorul unei sonde sterile. Fiecare dintre probe a fost apoi introdusă separat într-o concentraţie de $100 \mu \mathrm{l}$ cu o concentraţie reziduală de medicament pe bază de plante. Prezenţa zonei clare în jurul probei (dacă a existat) a fost analizată pentru a determina existenţa activităţii antibacteriene a probelor după incubarea plăcilor timp de 24 de ore. Diametrul zonei de inhibiţie a fost măsurat în $\mathrm{mm}$ şi înregistrat.

\section{Aplicarea în industria de pielărie}

\section{Conservarea pieilor}

S-au obţinut cinci piei de capră proaspăt jupuite dintr-un abator local şi fiecare piele a fost tăiată în patru sferturi. Pe fiecare dintre cele patru sferturi s-a aplicat o combinaţie de pastă de frunze de Cassia fistula + sare şi pastă de frunze de Psidium guajava + sare. Tabelul 1 ilustrează designul experimental pentru studiu. Toate materialele de conservare au fost aplicate pe partea de carne a pieilor raportate la greutatea pieilor crude. 
These experimental skins were allowed to be preserved at an ambient temperature of $31^{\circ} \mathrm{C}$ for 21 days.

\section{Sample Collection}

During the preservation period the experimental skins were physically examined for hair slip, smell and putrefaction. And small pieces of skins were collected on the $1^{\text {st }}, 3^{\text {rd }}, 7^{\text {th }}, 14^{\text {th }}$ and $21^{\text {st }}$ day and tested for biochemical parameters (moisture content, extractable hydroxyproline content and protein content) and microbial load.

On the $21^{\text {st }}$ day, both the control and preserved experimental skins were processed into leather. The soak liquors were collected and studied for the effluent characteristics (COD, TDS and TS). The processed leathers were tested for their physical properties, colour fastness. The results were compared with the control at the end.

\section{Biochemical Parameters}

\section{Determination of Moisture Content}

The experimental skin sample was weighed ( $25 \mathrm{~g}$ ) with silica crucible and noted as initial weight value (A). This was then placed in hot air oven at $98^{\circ} \mathrm{C}$ for $3 \mathrm{hrs}$, cooled in a desiccator and weighed. This will give the final weight $(B)$. The percentage of moisture content is measured by:
Aceste piei experimentale au fost păstrate la o temperatură ambiantă de $31^{\circ} \mathrm{C}$ timp de 21 de zile.

\section{Colectarea probelor}

În timpul perioadei de conservare, pieile experimentale au fost examinate fizic pentru a determina gradul de înlăturare al părului, mirosul şi putrefacţia. S-au colectat bucăţi mici de piei după 1, 3, 7, 14 şi 21 de zile şi s-au testat pentru determinarea parametrilor biochimici (conţinutul de umiditate, conţinutul de hidroxiprolină extractibilă şi conţinutul de proteine) şi a încărcăturii microbiene.

În ziua 21, atât pieile martor, cât şi cele experimentale conservate au fost prelucrate până la stadiul de piele finită. Lichidul de la înmuiere a fost colectat şi studiat pentru a determina caracteristicile efluentului (CCO, TDS şi TS). Pieile prelucrate au fost testate pentru a determina proprietăţile fizice şi rezistenţa culorii acestora. Rezultatele au fost comparate cu cele ale probelor martor la final.

\section{Parametrii biomecanici}

\section{Determinarea conţinutului de umiditate}

Proba de piele experimentală a fost cântărită ( 25 g) într-un creuzet de silice şi s-a notat valoarea iniţială a greutăţii (A). Proba a fost apoi pusă în cuptorul cu aer cald la $98^{\circ} \mathrm{C}$ timp de 3 ore, s-a răcit într-un desicator şi sa cântărit. S-a obţinut astfel greutatea finală (B). Procentul de umiditate s-a măsurat prin:

$$
\begin{gathered}
\% \text { of moisture content }=(A-B) / A \times 100 \\
\% \text { din continutul de umiditate }=(A-B) / A \times 100
\end{gathered}
$$

\section{Hydroxyproline Estimation}

The preserved skin sample $(5 \mathrm{~g})$ was suspended in ten times distilled water at $40-50$ rpm for 30 minutes. The suspended solution was analysed for hydroxyproline by Woessner method [29]. A small sample of the suspended solution was hydrolysed with $6 \mathrm{~N} \mathrm{HCl}$ overnight at $130^{\circ} \mathrm{C}$. To this, $1 \mathrm{ml}$ of Chloramine $\mathrm{T}$ was shaken for a few minutes and allowed to stand for 20 minutes. To this, $1 \mathrm{ml}$ of perchloric acid is added and mixed well and allowed to stand for 5 minutes, followed by $1 \mathrm{ml}$ of PDAB ( $p$-dimethylaminobenzaldehyde) and mixed well. Then the tubes are placed at $60^{\circ} \mathrm{C}$ in a water

\section{Estimarea hidroxiprolinei}

Proba de piele conservată $(5 \mathrm{~g})$ a fost suspendată în apă distilată de zece ori la 40-50 rpm timp de 30 minute. Soluţia în suspensie a fost analizată pentru a determina conţinutul de hidroxiprolină prin metoda Woessner [30]. O probă mică din soluţia de suspensie sa hidrolizat cu acid clorhidric $6 \mathrm{~N}$ peste noapte la $130^{\circ} \mathrm{C}$. $\mathrm{S}$-a adăugat $1 \mathrm{ml}$ de cloramină $\mathrm{T}$ şi s-a agitat timp de câteva minute, apoi s-a lăsat să stea timp de 20 de minute. S-a adăugat $1 \mathrm{ml}$ de acid percloric şi $\mathrm{s}$-a amestecat bine, apoi s-a lăsat să stea timp de 5 minute, urmat de $1 \mathrm{ml}$ de PDAB (p-dimetilaminobenzaldehidă) 
bath for 20 minutes and then cooled with tap water for 5 minutes. The absorbency of the solution is determined spectrophotometrically at $557 \mathrm{~nm}$. The hydroxyproline values may be determined directly from the standard curve. The results are expressed in

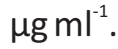

\section{Protein Estimation}

The supernatant solution $(1 \mathrm{ml})$ was obtained after suspending the experimental skin sample in ten times the distilled water. To the supernatant sample, alkaline copper sulphate reagent was added and mixed well and incubated at room temperature for 10 minutes. To this $0.2 \mathrm{ml}$ of the Folin-Ciocalteu solution was added and incubated for 30 minutes and read spectrophotometrically at $600 \mathrm{~nm}[30]$. The results are expressed in $\mathrm{mg} \mathrm{ml}^{-1}$.

\section{Microbial Study}

\section{Determination of Bacterial Load}

The experimental cured skin ( $10 \mathrm{~g})$ was suspended in $90 \mathrm{ml}$ of sterile distilled water and kept in an orbital shaker at $40-50 \mathrm{rpm}$ for 30 minutes. The suspended solution ( $1 \mathrm{ml}$ ) was serially diluted in $9 \mathrm{ml}$ normal saline till $10^{-3}$ dilution. From the diluted tube $0.1 \mathrm{ml}$ was poured in sterile nutrient agar plates before solidifying and rotated clockwise and anticlockwise for five times and allowed to solidify (carried out by pour plate technique) and incubated for $24 \mathrm{hrs}$ at $37^{\circ} \mathrm{C}$. Then the numbers of viable bacterial colonies were counted in CFU ml ${ }^{-1}$.

\section{Analysis of Exhaust Soak Liquor Generated}

$C O D$

COD of soak liquors was determined according to ISO 15705:2002. To the soak liquor $(2.5 \mathrm{ml})$ a pinch of mercuric sulphate was added, followed by $1.5 \mathrm{ml}$ of potassium dichromate and digested at $148^{\circ} \mathrm{C}$ for $2 \mathrm{hrs}$ in COD digester. The digested solution with 3 or 4 drops of Ferroin indicator was titrated against Ferrous Ammonium Sulphate (FAS). The results are reported in $\mathrm{mgl}^{-1}$. şi s-a amestecat bine. Apoi eprubetele au fost introduse într-o baie de apă la $60^{\circ} \mathrm{C}$ timp de 20 minute şi apoi s-au răcit cu apă de la robinet timp de 5 minute. Absorbanţa soluţiei s-a determinat spectrofotometric la $557 \mathrm{~nm}$. Valorile hidroxiprolinei pot fi determinate direct din curba standard. Rezultatele sunt exprimate în $\mathrm{g} \mathrm{m} \mathrm{ml}^{-1}$.

\section{Estimarea proteinei}

Soluţia de supernatant $(1 \mathrm{ml}) \mathrm{s}$-a obţinut după suspendarea probei de piele experimentală în apă distilată de zece ori. Peste proba de supernatant s-a adăugat reactiv alcalin sulfat de cupru şi s-a amestecat bine, apoi s-a incubat la temperatura camerei timp de 10 minute. S-au adăugat $0,2 \mathrm{ml}$ de soluţie FolinCiocalteu şi s-a incubat timp de 30 minute, apoi s-a citit spectrofotometric la $600 \mathrm{~nm}$ [30]. Rezultatele sunt exprimate în $\mathrm{mg} \mathrm{ml}^{-1}$.

\section{Studiu microbian}

\section{Determinarea încărcării bacteriene}

Pielea experimentală conservată $(10 \mathrm{~g})$ a fost suspendată în $90 \mathrm{ml}$ de apă distilată sterilă şi s-a menţinut într-un agitator orbital la 40-50 rpm timp de 30 minute. Soluţia de suspensie $(1 \mathrm{ml})$ a fost diluată în serie în $9 \mathrm{ml}$ de soluţie salină normală până la o diluare de $10^{-3}$. Din eprubeta cu soluţie diluată s-a turnat $0,1 \mathrm{ml}$ în plăci cu agar steril înainte de solidificare şi s-au rotit în sens orar şi antiorar de cinci ori, apoi s-au lăsat să se solidifice (prin tehnica de turnare în placă) şi s-au incubat timp de 24 ore la $37^{\circ} \mathrm{C}$. Apoi, s-au numărat coloniile de bacterii viabile în CFU $\mathrm{ml}^{-1}$.

\section{Analiza apei reziduale de la înmuiere}

\section{Consumul chimic de oxigen (CCO)}

CCO al efluenţilor de la înmuiere a fost determinat în conformitate cu ISO 15705:2002. Peste soluţia de înmuiere $(2,5 \mathrm{ml}) \mathrm{s}$-a adăugat puţin sulfat mercuric, urmat de $1,5 \mathrm{ml}$ de dicromat de potasiu şi s-a digerat la $148^{\circ} \mathrm{C}$, timp de 2 ore în digestorul CCO. Soluţia digerată cu 3 sau 4 picături de indicator Ferroin a fost titrată cu sulfat de amoniu feros (FAS). Rezultatele sunt raportate în $\mathrm{mgl}^{-1}$. 


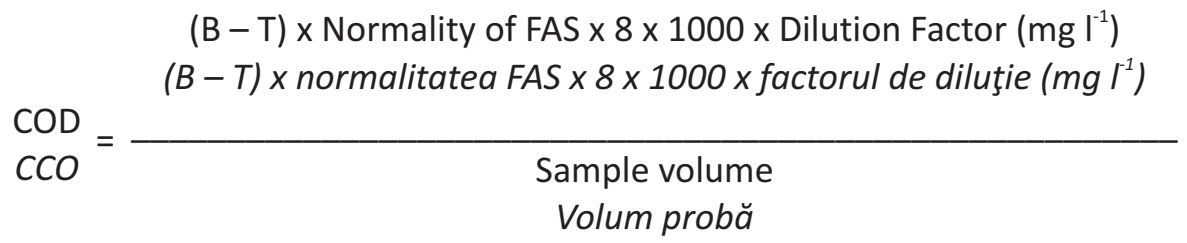

where, $\mathrm{B}=$ Water Blank; $\mathrm{T}=$ Test Sample

TDS

An evaporating dish was washed three times and dried. The soak liquor was stirred, $50 \mathrm{ml}$ of sample was pipetted out and filtered using a filter paper. The filtrate was transferred onto the dried dish in hot air oven, which was then cooled down in a desiccator and weighed. The result was expressed in $\mathrm{mgl}^{-1}$. unde $\mathrm{B}=$ proba de apă martor; $\mathrm{T}$ = proba de testat

Substanţe solubile totale (TDS)

S-a spălat de trei ori o capsulă de evaporare şi s-a uscat. S-a agitat lichidul de înmuiere, s-au luat cu o pipetă $50 \mathrm{ml}$ de probă şi s-au filtrat folosind hârtie de filtru. Filtratul a fost transferat în capsula uscată în cuptorul cu aer cald şi a fost apoi răcit într-un desicator şi cântărit. Rezultatul a fost exprimat în $\mathrm{mg} \mathrm{I}^{-1}$.

TDS in $\mathrm{mg}^{-1}=(A-B) \times 1000 /$ Volume of sample taken

TDS in $m g I^{1}=(A-B) \times 1000 /$ Volumul probei studiate

where, $\mathrm{A}=$ weight of dried residue + dish, $\mathrm{mg} ; \mathrm{B}=$ weight of dish, $\mathrm{mg}$.

\section{TS (Total Solids)}

Empty weight of a clean dry dish was taken. With constant stirring $50 \mathrm{ml}$ of the soak liquor sample was taken a dry dish. The content was evaporated in hot air oven and cooled. The dry weight of the dish was expressed in $\mathrm{mgl}^{-1}$. unde $A$ = greutatea reziduului uscat + capsulă, $\mathrm{mg}$; $\mathrm{B}$ = greutatea capsulei, mg.

\section{Substanţe solide totale (TS)}

S-a cântărit greutatea unei capsule curate şi uscate. Agitând constant, s-au luat $50 \mathrm{ml}$ din proba de efluent de la înmuiere într-o capsulă uscată. Conţinutul a fost evaporat în cuptorul cu aer cald şi s-a răcit. Greutatea uscată a capsulei a fost exprimată în $\mathrm{mg}^{-1}$.

TS in $\mathrm{mg}^{-1}=(\mathrm{A}-\mathrm{B}) \times 1000 /$ Volume of sample taken

TS în $m g I^{1}=(A-B) \times 1000 /$ Volumul probei studiate

where, $A=$ weight of dried residue + dish, $\mathrm{mg} ; \mathrm{B}=$ weight of dish, $\mathrm{mg}$.

\section{Leather Quality Analysis}

\section{Physical Characteristics of Crust Leathers}

The leather samples made from control and experimental samples were taken for physical testing measurements and the samples were cut from the official sampling position (IUP 2 method). The leather samples were conditioned at $20 \pm 2^{\circ} \mathrm{C}$ and $65 \pm 4 \% \mathrm{RH}$ for 48 hours before the study. The tensile strength, elongation at break, tear strength and grain crack unde $A$ = greutatea reziduului uscat + capsulă, mg; B = greutatea capsulei, $\mathrm{mg}$.

\section{Analiza calităţii pielii}

\section{Caracteristicile fizice ale pieilor crust}

Probele de piele finită realizate din probele martor şi din cele experimentale au fost supuse încercărilor fizice, probele fiind tăiate conform metodei oficiale de prelevare (metoda IUP 2). Probele de piele au fost condiţionate la $20 \pm 2^{\circ} \mathrm{C}$ şi $65 \pm 4 \% \mathrm{RH}$ timp de 48 de ore înainte de studiu. S-au determinat rezistenţa la rupere, alungirea la rupere, rezistenţa la sfâşiere şi rezistenţa 
strength were measured as per IUP 6, IUP 8 and IUP 9 methods respectively.

\section{Estimation of Colour Difference}

The control and optimized experimental crust leathers were subjected to the reflectance measurements using a Milton Roy colour mate HDS instrument. Colour measurement ( $L, a, b, h$ and $C$ ) was recorded and the total colour difference $(\Delta \mathrm{E})$ and hue difference $(\Delta \mathrm{H})$ were calculated using the following equations: feţei la crăpare conform metodelor IUP 6, IUP 8, respectiv IUP 9.

\section{Estimarea diferenţei de culoare}

Pieile crust martor şi cele experimentale optimizate au fost supuse măsurătorilor de reflectanţă folosind un instrument HDS Milton Roy de determinarea culorii. Măsurarea culorii ( $L, a, b, h$ şi C) a fost înregistrată, iar diferenţa de culoare totală $(\Delta E)$ şi diferenţa de nuanţă $(\Delta \mathrm{H})$ s-au calculat cu ajutorul următoarelor ecuaţii:

$$
\begin{aligned}
& \Delta E=\sqrt{ } \Delta L^{2}+\Delta a^{2}+\Delta b^{2} \\
& \Delta H=\sqrt{ } \Delta E^{2}-\Delta L^{2}-\Delta C^{2}
\end{aligned}
$$

where $\Delta \mathrm{E}=$ Overall colour difference; $\Delta \mathrm{L}=$ Lightness difference; $\Delta a$ and $\Delta b=$ difference of 'a' and ' $b$ ' values, where ' $a$ ' represents the red and green axis and ' $b$ ' represents the yellow and blue axis; $\Delta \mathrm{H}$, hue difference, $\Delta \mathrm{C}$, chromaticity difference.

\section{RESULTS AND DISCUSSION}

The leaf extracts of Cassia fistula and Psidium guajava were studied for their antibacterial activities against collagen degrading bacteria. The ethanol, hexane and water extracts of Cassia fistula and Psidium guajava leaf were dark brown, dark green and brown in colour. The Ethanol, Hexane and water extracts of Psidium guajava leaf appeared to be dark brown, dark green and brown in colour respectively. unde $\Delta \mathrm{E}=$ diferenţa de culoare în ansamblu; $\Delta \mathrm{L}=$ diferenţa de luminozitate; $\Delta a$ şi $\Delta b=$ diferenţa valorilor „a" şi „,b”, unde „a” reprezintă axa roşu-verde, iar „b” reprezintă axa galben-albastru; $\Delta \mathrm{H}=$ diferenţa de nuanţă, $\Delta C=$ diferenţa cromatică.

\section{REZULTATE ŞI DISCUTII}

S-au studiat extractele de frunze de Cassia fistula şi Psidium guajava în privinţa activităţii antibacteriene a acestora împotriva bacteriilor care degradează colagenul. Extractele în etanol, hexan şi apă ale frunzelor de Cassia fistula şi Psidium guajava au avut culorile maro închis, verde închis şi maro. Extractele în etanol, hexan şi apă din frunzele de Psidium guajava au avut culorile maro închis, verde închis, respectiv maro.

Table 1: Antibacterial activity of Cassia fistula extracts

Tabelul 1: Activitatea antibacteriană a extractelor de Cassia fistula

\begin{tabular}{c|c|c|c|}
\multirow{2}{*}{$\begin{array}{c}\text { Name of the bacteria } \\
\text { Denumirea bacteriei }\end{array}$} & \multicolumn{3}{|c|}{$\begin{array}{c}\text { Zone of clearance in } \mathrm{mm} \\
\text { Zona de inhibiţie în } \mathrm{mm}\end{array}$} \\
\cline { 2 - 4 } & $\begin{array}{c}\text { Ethanol } \\
\text { Etanol }\end{array}$ & $\begin{array}{c}\text { Hexane } \\
\text { Hexan }\end{array}$ & $\begin{array}{c}\text { Water } \\
\text { Apă }\end{array}$ \\
\hline \hline Bacillus sp. & 1.5 & 1.3 & NIL $^{*}$ \\
\hline Klebsiella sp. & 1.9 & 0.9 & NIL $^{*}$ \\
\hline Proteus sp. & 1.5 & 1.2 & 0.8 \\
\hline
\end{tabular}

*NIL - No clear zone was noted

*NIL - Nu s-a observat o zonă de inhibiţie clară 
Table 2: Antibacterial activity of Psidium guajava extracts

Tabelul 2: Activitatea antibacteriană a extractelor de Psidium guajava

\begin{tabular}{c|c|c|c|}
\multirow{2}{*}{$\begin{array}{c}\text { Name of the bacteria } \\
\text { Denumirea bacteriei }\end{array}$} & \multicolumn{3}{|c}{$\begin{array}{c}\text { Zone of clearance in } \mathrm{mm} \\
\text { Zona de inhibiţie in } \mathrm{mm}\end{array}$} \\
\cline { 2 - 4 } & $\begin{array}{c}\text { Ethanol } \\
\text { Etanol }\end{array}$ & $\begin{array}{c}\text { Hexane } \\
\text { Hexan }\end{array}$ & $\begin{array}{c}\text { Water } \\
\text { Apă }\end{array}$ \\
\hline Bacillus sp. & 2.3 & 1.1 & NIL $^{*}$ \\
\hline Klebsiella sp. & 1.9 & 1.1 & NIL $^{*}$ \\
\hline Proteus sp. & 1.7 & 2 & 1.2 \\
\hline
\end{tabular}

*NIL - No clear zone was noted

*NIL - Nu s-a observat o zonă de inhibiţie clară

The study on antibacterial activity of Cassia fistula and Psidium guajava extracts are recorded in Tables 1 and 2 respectively. From the results, it is evident that there is a good antibacterial activity for Ethanolic extracts of Cassia fistula and Psidium guajava as seen from their zone of clearance of 1.5 $\mathrm{mm}$ and $2.3 \mathrm{~mm}$, respectively, against Bacillus sp. The Ethanolic extracts of Cassia fistula and Psidium guajava leaves produced a zone of clearance of 1.9 $\mathrm{mm}$ against Klebsiella sp also. The Ethanolic extract of Cassia fistula leaves and the Hexane extract of Psidium guajava leaves displayed $1.5 \mathrm{~mm}$ and $2.0 \mathrm{~mm}$ zones of clearance, respectively, against Proteus sp. Thus, the antibacterial study revealed significant antibacterial activity of Cassia fistula and Psidium guajava against bacteria isolated from skins showing collagenolytic and gelatine liquefying behaviours. Studies by Nayan R. Bhalodia and V. J. Shukla [31] have also shown the antibacterial potential of Cassia fistula against Gram positive and Gram negative bacteria. Biswas et al. [32] have studied and shown the antibacterial activity of Psidium guajava against Gram positive and Gram negative bacteria. Thus, evidences in general and our own experiments in specific stamp the candidacy of Cassia fistula and Psidium guajava as potential preservants of skin against bacterial invasion.
Rezultatele studiului privind activitatea antibacteriană a extractelor de Cassia fistula şi Psidium guajava sunt prezentate în Tabelele 1 şi 2. Rezultatele arată clar că extractele etanolice de Cassia fistula şi Psidium guajava au o activitate antibacteriană bună, aşa cum se vede din zona de inhibiţie de $1,5 \mathrm{~mm}$, respectiv $2,3 \mathrm{~mm}$, împotriva Bacillus sp. De asemenea, extractele etanolice de Cassia fistula şi Psidium guajava au determinat o zonă de inhibiţie de 1,9 mm împotriva Klebsiella sp. Extractul etanolic de Cassia fistula şi extractul în hexan al Psidium guajava au prezentat o zonă de inhibiţie de $1,5 \mathrm{~mm}$, respectiv $2,0 \mathrm{~mm}$, împotriva Proteus sp. Astfel, studiul antibacterian a relevat activitatea antibacteriană semnificativă a extractelor de Cassia fistula şi Psidium guajava împotriva bacteriilor izolate din piei care prezintă comportament de lichefiere a colagenului şi gelatinei. Studiile efectuate de către Nayan R. Bhalodia şi $\underline{\text {. J J. }}$ Shukla [31] au arătat, de asemenea, potenţialul antibacterian al Cassia fistula împotriva bacteriilor Gram pozitive şi Gram negative. Biswas şi colab. [32] au studiat şi demonstrat activitatea antibacteriană a Psidium guajava împotriva bacteriilor Gram pozitive şi Gram negative. Astfel, dovezile existente, în general, şi propriile noastre experimente, în particular, demonstrează potenţialul extractelor de Cassia fistula şi Psidium guajava de a conserva şi proteja pielea împotriva invaziei bacteriene. 
Table 3: Concentration of salt and Cassia fistula extract, Psidium guajava extracts applied on the skin based on its green weight Tabelul 3: Concentraţia de sare şi extracte de Cassia fistula şi Psidium guajava aplicate pe piele relativ la greutatea pielii crude

\begin{tabular}{|c|c|c|c|}
\hline \multirow{2}{*}{$\begin{array}{l}\text { Sample no. } \\
\text { Nr. probă }\end{array}$} & \multicolumn{3}{|c|}{$\begin{array}{l}\% \text { based on green weight of the skin } \\
\% \text { relativ la greutatea pielii crude }\end{array}$} \\
\hline & $\begin{array}{l}\text { Salt } \% \\
\text { Sare } \%\end{array}$ & $\begin{array}{l}\text { Leaves extract \% } \\
\text { Extract plante \% } \\
\text { (Cassia Fistula) }\end{array}$ & $\begin{array}{l}\text { Leaves extract \% } \\
\text { Extract plante \% } \\
\text { (Psidium guajava) }\end{array}$ \\
\hline 1 & 40 & $\begin{array}{l}\mathrm{Nil} \\
\mathrm{Nul}\end{array}$ & $\begin{array}{l}\text { Nil } \\
\text { Nul }\end{array}$ \\
\hline 2 & 15 & 15 & Nil \\
\hline 3 & 15 & 10 & $\begin{array}{l}\text { Nil } \\
\text { Nul }\end{array}$ \\
\hline 4 & 15 & 5 & Nil \\
\hline 5 & 10 & 15 & Nil \\
\hline 6 & 10 & 10 & Nil \\
\hline 7 & 10 & 5 & Nil \\
\hline 8 & 5 & 15 & Nil \\
\hline 9 & 5 & 10 & Nil \\
\hline 10 & 5 & 5 & Nil \\
\hline 11 & 15 & $\begin{array}{l}\mathrm{Nil} \\
\mathrm{Nul}\end{array}$ & 15 \\
\hline 12 & 15 & Nil & 10 \\
\hline 13 & 15 & $\begin{array}{l}\mathrm{Nil} \\
\mathrm{Nul}\end{array}$ & 5 \\
\hline 14 & 10 & Nil & 15 \\
\hline 15 & 10 & $\begin{array}{l}\mathrm{Nil} \\
\mathrm{Nul}\end{array}$ & 10 \\
\hline 16 & 10 & Nil & 5 \\
\hline 17 & 5 & $\begin{array}{l}\mathrm{Nil} \\
\mathrm{Nul}\end{array}$ & 15 \\
\hline 18 & 5 & Nil & 10 \\
\hline 19 & 5 & $\begin{array}{l}\mathrm{Nil} \\
\mathrm{Nul}\end{array}$ & 5 \\
\hline
\end{tabular}


In the experiments, the Cassia fistula and Psidium guajava with different combinations of salt as mentioned in Table 3 were preserved for 21 days. During the organoleptic evaluation of the experimental skins preserved with the paste of Cassia fistula and Psidium guajava showed hair slip, smell and putrefaction on the $3^{\text {rd }}$ day for samples 5, 8, 9, 10, hence were discarded. But there was no hair slip, smell and putrefaction for samples no. 1, 2, 3, 4, 6, 7 and 11 , hence they were preserved for 21 days. These observations indicate the autolysis and bacterial degradation of experimental skins. The skins were monitored and studies were carried out in the incubation periods. It seemed that $15 \%$ leaves extract with $15 \%$ salt and $10 \%$ leaves extract with $10 \%$ salt gave the satisfactory preservation system.
În experimentele de faţă, pieile au fost conservate timp de 21 de zile utilizând Cassia fistula şi Psidium guajava în diferite combinaţii cu sare, aşa cum se menţionează în Tabelul 3. În urma evaluării organoleptice a pieilor experimentale conservate $\mathrm{cu}$ pastă de Cassia fistula şi Psidium guajava s-au observat căderea părului, miros şi putrefacţie în a 3-a zi în cazul probelor 5, 8, 9, 10; prin urmare, acestea au fost eliminate. Pe de altă parte, în cazul probelor 1, 2, 3, 4, 6, 7 şi 11 nu s-au observat căderea părului, miros şi putrefacţie; prin urmare, aceste probe au fost conservate timp de 21 de zile. Aceste observaţii indică autoliza şi degradarea bacteriană a pieilor experimentale. Pieile au fost monitorizate şi s-au efectuat studii în perioadele de incubaţie. Sistemul de conservare satisfăcător a constat în combinarea a $15 \%$ extract de frunze cu $15 \%$ sare şi $10 \%$ extract de frunze cu $10 \%$ sare.

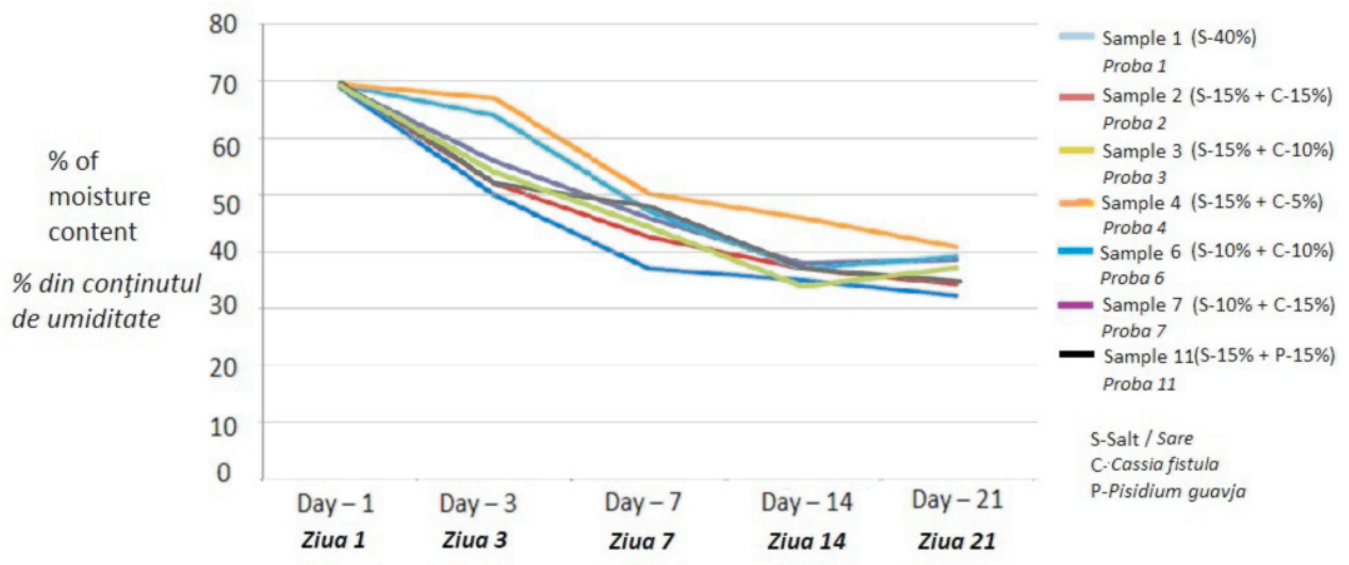

Figure 1. Moisture content of the experimental skins in percentage

Figura 1. Conţinutul de umiditate al pieilor testate, exprimat în procente

From the Figure 1, it is seen that the moisture contents of experimental skins were around $70 \%$ on the first day and there was a steady decrease in the moisture contents of up to $40 \%$ after 21 days of preservation. The moisture content of the skin is a crucial factor as the microbes like bacteria need moisture for their growth and survival. Whereas the conventional salt cured skins showed up to $30 \%$ reduction in the moisture content after 21 days of preservation, similar experiments carried out with Para Chloro Meta Cresol (PCMC) also were reported to show a $40 \%$ reduction in moisture content [33]. Salt based preservation is efficient because of
Din Figura 1 se observă că, în cazul pieilor experimentale, conţinutul de umiditate a fost de aproximativ $70 \%$ în prima zi şi a existat o scădere constantă a conţinutului de umiditate de până la $40 \%$ după 21 de zile de conservare. Conţinutul de umiditate al pielii este un factor decisiv, întrucât microbii precum bacteriile au nevoie de umiditate pentru a creşte şi supravieţui. Întrucât pieile conservate în mod tradiţional cu sare au prezentat o reducere de până la $30 \%$ a conţinutului de umiditate după 21 de zile de conservare, au fost raportate experimente similare efectuate $\mathrm{cu}$ para-clor-meta-crezol (PCMC), care prezintă o reducere de $40 \%$ a conţinutului de umiditate [33]. Conservarea pe 
the dual role of salt as dehydrant and bacteriostat. This shows the tenacity of the proposed less salt, phytobased preservation in dehydrating the moisture contents of the skins as low as the other methods of preservation in literature.

The soluble protein content of the experimental skins and conventional salt cured skins are depicted in Fig 2. bază de sare este eficientă datorită rolului dublu al sării ca deshidratant şi bacteriostatic. Acest lucru arată tenacitatea metodei de conservare propuse, pe bază de plante şi cu mai puţină sare, la deshidratarea pieilor, comparabilă cu celelalte metode deconservare din literatură.

Conţinutul de proteină solubilă al pieilor experimentale şi al celor conservate convenţional $\mathrm{cu}$ sare este ilustrat în Figura 2.
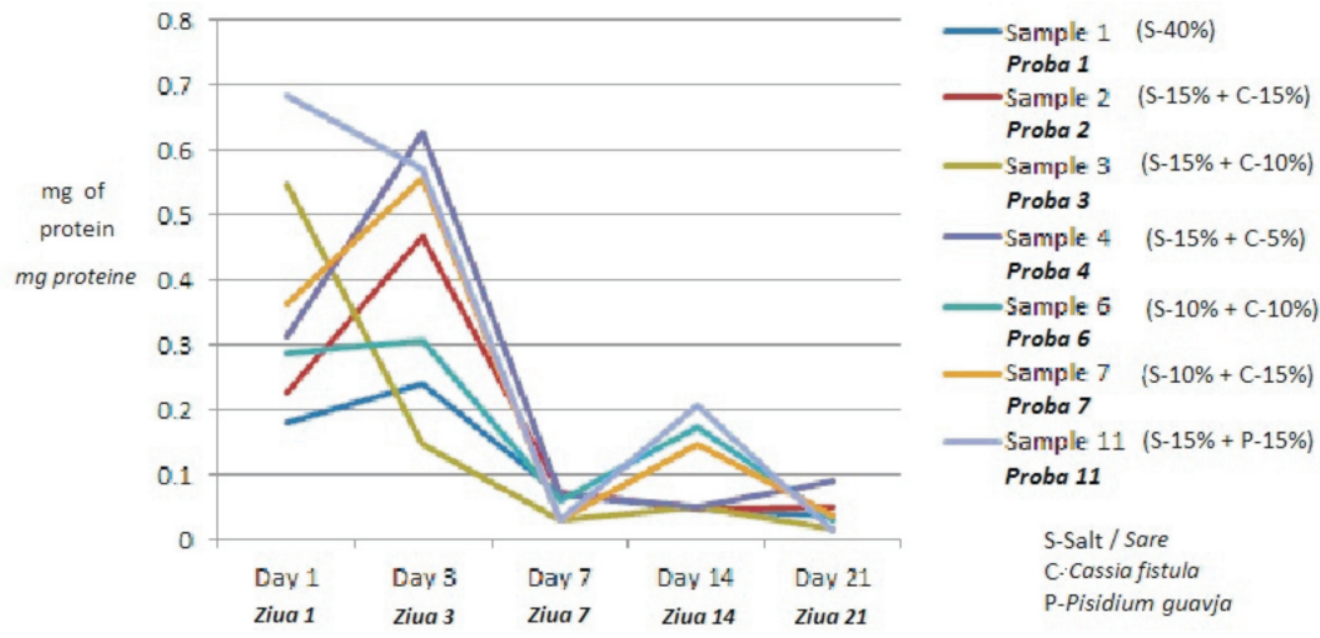

Figure 2. Determination of Soluble Protein content in phyto-preserved goat skins

Figura 2. Determinarea conţinutului de proteine solubile al pieilor de capră conservate cu ajutorul plantelor

The soluble proteins in the aqueous extract of the preserved skins indicate the extent of deterioration of the skin proteins. From the results, the soluble protein levels were found to be reducing below $0.1 \mathrm{mg} \mathrm{g}^{-1}$ of the skin on the $21^{\text {st }}$ day. Only the guava preserved skins with $15 \%$ leaf extract and $15 \%$ salt showed just over $0.2 \mathrm{mg}$ $\mathrm{g}^{-1}$ of the skin on the $14^{\text {th }}$ day but it eventually reduced further on the $21^{\text {st }}$ day. The Cassia fistula preserved skins showed remarkable reduction in soluble protein content by the $21^{\text {st }}$ day even that being superior to Guava leaves. Thus the antimicrobial effect of both Cassia and Guava during preservation was manifested in the aqueous extracts of the preserved skins samples in a brilliant fashion.

The total content of collagen in the skin can be measured by evaluating the hydroxyproline content. Thus, by measuring the hydroxyproline content in the aqueous extracts of skins, the efficacy of preservation can be determined. The release of hydroxyproline in the aqueous extracts of the experimental skins is presented in Figure 3.
Proteinele solubile din extractul apos al pieilor conservate indică gradul de deteriorare a proteinelor pielii. Din rezultate, $\mathrm{s}$-a constatat reducerea nivelurilor de proteine solubile sub $0,1 \mathrm{mg} \mathrm{g}^{-1}$ în ziua 21. Doar pieile conservate cu $15 \%$ extract de frunze de guava şi $15 \%$ sare au prezentat puţin peste $0,2 \mathrm{mg} \mathrm{g}^{-1}$ în ziua a $14-a$, dar în cele din urmă s-a redus şi mai mult în ziua 21 . Pieile conservate cu Cassia fistula au prezentat o reducere remarcabilă a conţinutului de proteină solubilă până în ziua 21 , fiind superioare celor tratate cu frunze de guava. Astfel, efectul antimicrobian al extractelor de cassia şi guava în timpul conservării a fost excelent în extractele apoase ale probelor de piei conservate.

Conţinutul total de colagen al pieilor poate $\mathrm{fi}$ măsurat prin evaluarea conţinutului de hidroxiprolină. Astfel, prin măsurarea conţinutului de hidroxiprolină din extractele apoase ale pieilor, poate fi determinată eficacitatea conservării. Hidroxiprolina eliberată în extractele apoase ale pieilor experimentale este prezentată în Figura 3. 


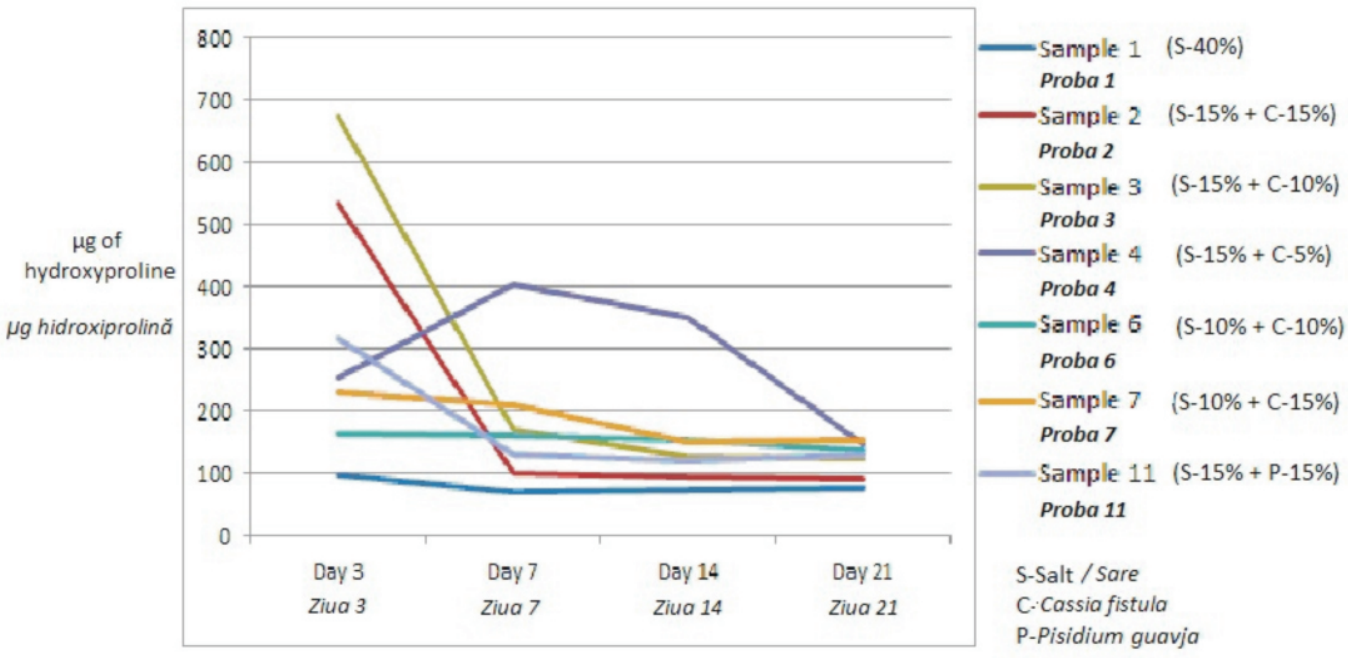

Figure 3. Determination of Soluble Hydroxyproline estimation from phyto-preserved goat skins

Figura 3. Determinarea hidroxiprolinei solubile estimate din pieile de capră conservate cu ajutorul plantelor

The release of hydroxyproline in the aqueous extracts of skins was found to be low in all the samples (below $500 \mu \mathrm{g} \mathrm{g}^{-1}$ of skin) on the $21^{\text {st }}$ day, in general. The inefficacy of preservation will be indicated with the maximum hydroxyproline release in the aqueous extracts of skins. This implies also to any microbial attack or degradation of the skin by external factors. Hence, the results prove the efficacy of preservation by Cassia fistula and guava with the proposed less salt preservation.
În general, eliberarea de hidroxiprolină în extractele apoase ale pieilor s-a dovedit a fi scăzută în cazul tuturor probelor (sub $500 \mu \mathrm{g} \mathrm{g}^{-1}$ din piele), în ziua 21. Ineficacitatea conservării va fi indicată de eliberarea maximă de hidroxiprolină în extractele apoase ale pieilor. Acest lucru este valabil, de asemenea, şi pentru orice tip de atac microbian sau degradare a pielii cauzată de factori externi. Prin urmare, rezultatele dovedesc eficacitatea conservării propuse cu extracte de Cassia fistula şi guava şi mai puţină sare.

Table 4: Determination of bacterial count from skin sample

Tabelul 4: Determinarea numărului de bacterii din probele de piei

\begin{tabular}{|c|c|c|c|c|c|c|}
\hline \multirow{2}{*}{$\begin{array}{l}\text { Name of the plant } \\
\text { Denumirea plantei }\end{array}$} & \multirow{2}{*}{$\begin{array}{l}\text { Sample no. } \\
\text { Nr. probă }\end{array}$} & \multicolumn{5}{|c|}{ 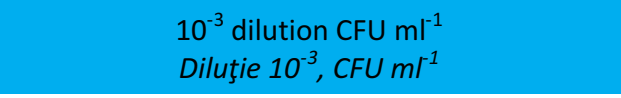 } \\
\hline & & $\begin{array}{l}\text { Day } 1 \\
\text { Ziua } 1\end{array}$ & $\begin{array}{l}\text { Day } 3 \\
\text { Ziua } 3\end{array}$ & $\begin{array}{l}\text { Day } 7 \\
\text { Ziua } 7\end{array}$ & $\begin{array}{l}\text { Day } 14 \\
\text { Ziua } 14\end{array}$ & $\begin{array}{l}\text { Day } 21 \\
\text { Ziua } 21\end{array}$ \\
\hline $\begin{array}{l}\text { Control } \\
\text { Martor }\end{array}$ & 1 & 10 & 4 & 2 & 2 & $\mathrm{NIL}^{*}$ \\
\hline Cassia fistula & 2 & 40 & 8 & 8 & 8 & NIL $^{*}$ \\
\hline Cassia fistula & 3 & 56 & 40 & 20 & $\mathrm{NIL}^{*}$ & $\mathrm{NIL}^{*}$ \\
\hline Cassia fistula & 4 & 40 & 36 & 8 & 4 & $\mathrm{NIL}^{*}$ \\
\hline Cassia fistula & 6 & 8 & 8 & 4 & 4 & $\mathrm{NIL}^{*}$ \\
\hline Cassia fistula & 7 & 12 & 12 & 4 & 4 & $\mathrm{NIL}^{*}$ \\
\hline Guava & 11 & 64 & 52 & 24 & 4 & $\mathrm{NIL}^{*}$ \\
\hline
\end{tabular}

*NIL - Zero number of colonies

*NIL - Zero colonii 
The bacterial load on samples from preserved skins is a direct indicator of putrefaction. In other words, the load indicates also the efficiency of preservation. Table 4 shows the bacterial population of control and experimental skins at different time intervals till the $21^{\text {st }}$ day of preservation. The results indicate that the colonies of bacteria were reducing in the skin samples as the preservation duration increased. Ultimately, there was no growth of colonies by the $21^{\text {st }}$ day because of the synergistic action of the antibacterial activity of Cassia fistula, Psidium guajava and bacteriostatic activity of salt. Thus the efficiency of preservation with cleaner phyto-preservation employed in this study stands certified.
Încărcătura bacteriană a probelor de piei conservate este un indicator direct al putrefacţiei. Cu alte cuvinte, încărcătura bacteriană indică, de asemenea, eficienţa conservării. Tabelul 4 prezintă populaţia bacteriană a pieilor martor şi a celor experimentale la diferite intervale de timp până în ziua 21 de conservare. Rezultatele indică reducerea coloniilor de bacterii din probele de piele odată cu creşterea duratei de conservare. În cele din urmă, în ziua 21 nu s-a observat o creştere a coloniilor datorită acţiunii sinergice a activităţii antibacteriene a Cassia fistula, Psidium guajava şi activităţii bacteriostatice a sării. S-a dovedit astfel eficienţa metodei ecologice de conservare pe bază de plante experimentate în acest studiu.

Table 5: TDS, TS \& COD in soaked liquor

Tabelul 5: TDS, TS şi CCO în lichidul de înmuiere

\begin{tabular}{|c|c|c|}
\hline TDS $\mathrm{mg} \mathrm{I}^{-1}$ & $\mathrm{TS} \mathrm{mg} \mathrm{I}^{-1}$ & $\begin{array}{l}\mathrm{COD} \mathrm{mg} \mathrm{l}^{-1} \\
\mathrm{CCO} \mathrm{mg} \mathrm{l}^{-1}\end{array}$ \\
\hline 21 & 22 & 288 \\
\hline
\end{tabular}

The soak liquors were collected and tested for their TDS, TS and COD. The results showed that the TDS of the soak liquors of our phyto-based preserved skins got significant reduced. According to Springer and his colleagues [34], cost effective solutions to the TDS problem through either avoidance or end of pipe treatment are not yet forthcoming. Our preservation method is one such effort towards avoiding the TDS in the source itself. TS values using the phyto-based preservation method did not exceed the permissible TS level of $110 \mathrm{mg} \mathrm{l}^{-1}$ is also shown in the Table 5. These solid impurities cause turbidity in the receiving streams. COD level from soaking was $288 \mathrm{mg} \mathrm{I}^{-1}$ and was within the permissible COD level of (50-450) $\mathrm{mg} \mathrm{l}^{-1}$ [35] this indicates that the effluent is suitable to be let out into natural streams without affecting the aquatic organisms. Thus the phyto-preserved skins leave significantly lower TDS, TS and COD in the soak liquor making it a clear case of a cleaner way of preservation.
Efluentul de la înmuiere a fost colectat şi testat în vederea determinării TDS, TS şi CCO. Rezultatele au arătat că TDS al efluentului de la înmuierea pieilor conservate pe bază de plante s-a redus semnificativ. Potrivit lui Springer şi colab. [34], soluţii ieftine pentru problema TDS fie prin evitare, fie prin depoluare la capătul liniei nu sunt încă accesibile. Metoda noastră de conservare reprezintă un astfel de efort în vederea evitării prezenţei TDS. Valorile TS obţinute în urma utilizării metodei de conservare pe bază de plante nu au depăşit nivelul admis, de $110 \mathrm{mg} \mathrm{l}^{-1}$, fiind, de asemenea prezentate în Tabelul 5. Aceste impurităţi solide cauzează turbiditate în cursurile de apă receptoare. Nivelul CCO al lichidului de înmuiere a fost de $288 \mathrm{mg} \mathrm{I}^{-1}$, încadrându-se în nivelul CCO admisibil (50-450) $\mathrm{mg} \mathrm{I}^{-1}$ [35], ceea ce indică faptul că este recomandat ca efluentul să fie deversat în cursuri de apă naturale, fără a afecta organismele acvatice. Astfel, pieile conservate cu ajutorul plantelor duc la valori semnificativ mai mici ale TDS, TS şi CCO în lichidul de înmuiere, arătând în mod clar că este o metodă mai curată de conservare. 
Table 6: Physical properties of control and experimental leather

Tabelul 6: Proprietăţile fizice ale pieilor martor şi cele experimentale

\begin{tabular}{|c|c|c|c|c|c|c|c|c|}
\hline $\begin{array}{l}\text { No. } \\
\text { Nr. } \\
\text { crt. }\end{array}$ & $\begin{array}{l}\text { Properties } \\
\text { Proprietăţi }\end{array}$ & $\begin{array}{c}\text { Sample } 1 \\
\text { Control } \\
\text { Proba } 1 \\
\text { Martor }\end{array}$ & $\begin{array}{c}\text { Sample } 2 \\
\text { Proba } 2\end{array}$ & $\begin{array}{c}\text { Sample } 3 \\
\text { Proba } 3\end{array}$ & $\begin{array}{c}\text { Sample } 4 \\
\text { Proba } 4\end{array}$ & $\begin{array}{c}\text { Sample } 6 \\
\text { Proba } 6\end{array}$ & $\begin{array}{c}\text { Sample } 7 \\
\text { Proba } 7\end{array}$ & $\begin{array}{c}\text { Sample } 11 \\
\text { Proba } 11\end{array}$ \\
\hline 1. & $\begin{array}{c}\text { Tensile strength, } \mathrm{N} \mathrm{mm}^{-2} \\
\text { Rezistenţa la rupere, } \mathrm{N} \mathrm{mm}^{-2} \\
\text { Along } \\
\text { In lungime } \\
\text { Across } \\
\text { Transversal } \\
\text { Elongation at break, \% } \\
\text { Alungirea la rupere, \% } \\
\text { Along } \\
\text { In lungime } \\
\text { Across } \\
\text { Transversal }\end{array}$ & $\begin{array}{c}20.2 \\
17.1 \\
77 \\
67.5\end{array}$ & $\begin{array}{l}18.9 \\
10.1\end{array}$ & $\begin{array}{l}22.2 \\
21.1\end{array}$ & $\begin{array}{l}23.5 \\
13.2\end{array}$ & $\begin{array}{l}21.1 \\
7.2\end{array}$ & $\begin{array}{l}13.1 \\
11.1\end{array}$ & $\begin{array}{l}13.0 \\
19.4\end{array}$ \\
\hline 2. & $\begin{array}{c}\text { Tear strength, } \mathrm{N} \\
\text { Rezistenţa la sfâşiere, } \mathrm{N} \\
\text { Along } \\
\text { În lungime } \\
\text { Across } \\
\text { Transversal } \\
\text { Thickness, } \mathrm{mm} \\
\text { Grosime, } \mathrm{mm}\end{array}$ & $\begin{array}{c}43.3 \\
41.0 \\
0.7\end{array}$ & $\begin{array}{c}45.6 \\
36.6 \\
0.8\end{array}$ & $\begin{array}{l}57.1 \\
41.9 \\
0.63\end{array}$ & $\begin{array}{l}54.4 \\
50.6 \\
0.65\end{array}$ & $\begin{array}{l}38.7 \\
37.2 \\
0.72\end{array}$ & $\begin{array}{l}40.6 \\
31.3 \\
0.86\end{array}$ & $\begin{array}{l}53.2 \\
48.5 \\
0.80\end{array}$ \\
\hline 3. & $\begin{array}{c}\text { Lastometer } \\
\text { Dinamometru } \\
\text { Load at grain crack, } \mathrm{kg} \\
\text { Crăparea feţei la tracţiune, } \mathrm{kg} \\
\text { Distension at grain crack, } \mathrm{mm} \\
\text { Alungire la crăparea feţei, } \mathrm{mm}\end{array}$ & $\begin{array}{l}20 \\
9.3\end{array}$ & $\begin{array}{l}23 \\
9.2\end{array}$ & $\begin{array}{l}14 \\
6.8\end{array}$ & $\begin{array}{l}16 \\
8.6\end{array}$ & $\begin{array}{l}18 \\
9.1\end{array}$ & $\begin{array}{c}17 \\
10.3\end{array}$ & $\begin{array}{l}20 \\
9.5\end{array}$ \\
\hline
\end{tabular}

The physical strength properties of the experimental skins such as the tensile strength and elongation at break showed comparable results with the control and were found satisfactory (Table 6). Except for the neck portions of the leathers, tensile strength and tear load values of the experimental leathers were commensurate for upper leather. However, grain cracking property was observed to be comparable in all experimental leathers to the standards advised for upper leathers.
Proprietăţile de rezistenţă fizică ale pieilor experimentale, cum ar fi rezistenţa la rupere şi alungirea la rupere au prezentat rezultate comparabile cu probele martor şi au fost considerate satisfăcătoare (Tabelul 6). Cu excepţia porţiunilor de piele din zona gâtului, rezistenţa la rupere şi la sfâşiere ale pieilor experimentale au fost corespunzătoare pieilor pentru feţe de încălţăminte. Cu toate acestea, proprietatea de crăpare a feţei s-a constatat a fi comparabilă în cazul tuturor pieilor experimentale la standardele recomandate pentru feţe de încălţăminte. 
Table 7: Total colour difference values of control and experimental leathers

Tabelul 7: Valorile totale ale diferenţei de culoare pentru pieile martor şi cele experimentale

\begin{tabular}{|c|c|c|c|c|c|c|}
\hline $\begin{array}{c}\text { Sample No. } \\
\text { Nr. probă }\end{array}$ & $\mathrm{L}$ & $\mathrm{A}$ & $\mathrm{B}$ & $\mathrm{C}$ & $\mathrm{H}$ & $\mathrm{DL}$ \\
\hline \hline $\begin{array}{c}1 \text { - Control } \\
1 \text { - Martor }\end{array}$ & 69.790 & -4.774 & 56.722 & 57.5 & 92.537 & 10.545 \\
\hline 2 & 66.356 & -3.22 & 47.808 & 47.916 & 93.888 & 7.111 \\
\hline 3 & 69.936 & -2.914 & 58.162 & 58.235 & 92.903 & 10.691 \\
\hline 4 & 69.08 & -4.77 & 49.501 & 49.731 & 95.54 & 78.23 \\
\hline 5 & 68.96 & -2.2 & 56.72 & 58.65 & 92.25 & 9.715 \\
\hline 6 & 69.36 & -4.13 & 54.48 & 54.64 & 94.37 & 10.12 \\
\hline 7 & 71.48 & -4.81 & 55.173 & 55.23 & 95.04 & 7.28 \\
\hline
\end{tabular}

The leathers from the experimental and control skins were subjected to colour test. This test is performed to check the colour properties as some of the constituents in the plants like tannins may affect the colour of the leather during the process. The colour testing results in terms of colour and colour difference values of the control and experimental leathers are presented in Table 7. From the $\Delta \mathrm{L}$ and $\Delta C$ values shown in the Table 7 , it was observed that there was no major difference in the darkness value $(\Delta \mathrm{L})$ and colour intensity value $(\Delta \mathrm{C})$ between control and experimental leathers.

\section{CONCLUSION}

In the current investigation, Cassia fistula and Psidium guajava have been selected because of their excellent antibacterial and antifungal properties. The pastes of Cassia fistula leaves and Psidium guajava leaves along with reduced salt were found to preserve freshly flayed raw goat skins for 21 days. Especially $15 \%$ paste of Cassia fistula leaves and $15 \%$ paste of Psidium guajava leaves with $15 \%$ salt (based on green weight) proved very effective Phyto-based preservation combinations. The present study suggests the use of these leaves as alternate curing agents in combination with common salt reducing TDS and COD significantly in the soak liquor. The preserved experimental skins and control ( $40 \%$ salt based on green weight) were processed into leathers and showed comparable
Pieile finite realizate din probele de piei experimentale şi martor au fost supuse testului de culoare. Acest test este efectuat pentru a verifica proprietăţile de culoare, întrucât unii dintre constituenţii plantelor, cum ar fi taninurile, pot afecta culoarea pielii în timpul procesului. Rezultatele testelor de culoare pentru a determina valorile diferenţei de culoare ale pieilor martor şi ale celor experimentale sunt prezentate în Tabelul 7. Din valorile $\Delta \mathrm{L}$ şi $\Delta \mathrm{C}$ prezentate în Tabelul 7, s-a observat că nu a existat nicio diferenţă majoră în ceea ce priveşte valoarea luminozităţii $(\Delta \mathrm{L})$ şi valoarea intensităţii culorii $(\Delta C)$ între pieile martor şi cele experimentale.

\section{CONCLUZII}

În investigaţia de faţă, Cassia fistula şi Psidium guajava au fost selectate datorită proprietăţilor lor antibacteriene şi antifungice excelente. S-a constatat că pastele din frunze de Cassia fistula şi Psidium guajava, împreună cu o cantitate redusă de sare sunt adecvate pentru conservarea, timp de 21 de zile, a pieilor de capră crude proaspăt jupuite. În special, combinaţia de 15\% pastă din frunze de Cassia fistula şi 15\% pastă din frunze de Psidium guajava cu $15 \%$ sare (în funcţie de greutatea pielii crude) s-a dovedit a fi foarte eficientă pentru conservare. Studiul de faţă sugerează utilizarea acestor frunze ca agenţi de conservare alternativi, în combinaţie cu sare obişnuită, ducând la reducerea semnificativă a TDS şi CCO în lichidul de înmuiere. Pieile experimentale şi cele martor conservate ( $40 \%$ sare în funcţie de greutatea pielii crude) au fost prelucrate până la stadiul de piele 
properties which is evident from the physical testing and colour testing values. Further studies aimed at the isolation of bioactive compounds from the crude extracts are in progress to intensify the curing process as such. Thus, a new vista in curing the raw skins and hides averting pollution caused by common salt in tanneries unfurls leading to the development of a cleaner curing technology.

\section{Acknowledgements}

The authors thank ZERIS, a XII Five year plan network project of CSIR-CLRI for the funding supports. The authors thank Mrs. Malathy Jawahar, CSIR-CLRI, for her support in colour testing, Mr. Mohan, CSIR-CLRI, for his support in physical testing of leather samples and Dr. Ramesh Kannan, CSIR-CLRI, for his support in the initial screening of plants, and the student interns Swetha, S.K. and Surekha, K. finită şi au prezentat proprietăţi comparabile, după cum reiese clar din valorile obţinute la testarea proprietăţilor fizice şi la testarea culorilor. Studii suplimentare care vizează izolarea compuşilor bioactivi din extractele brute sunt în curs de desfăşurare pentru a intensifica procesul de conservare. Astfel, se naşte o nouă viziune privind conservarea pieilor crude care evită poluarea cu sare în tăbăcării şi care duce la dezvoltarea unei tehnologii mai curate de conservare.

\section{Mulţumiri}

Autorii mulţumesc proiectului ZERIS al CISR-CLRI, un proiect de reţea pe baza unui plan pe cinci ani, pentru sprijinul financiar. Autorii mulţumesc doamnei Malathy Jawahar, CISR-CLRI, pentru sprijinul acordat la testarea culorii, domnului Mohan, CISR-CLRI, pentru sprijinul acordat la testarea fizică a probelor de piele, Dr. Ramesh Kannan, CISR-CLRI, pentru sprijinul acordat la selectarea iniţială a plantelor,şi studenţilor stagiariSwetha, S.K. şiSurekha, K.

\section{REFERENCES}

1. Cassano, A., Molinari, R., Romano, M., Drioli, E., Treatment of aqueous effluents of the leather industry by membrane processes: A review, J MembrSci, 2001, 181, 1, 111-126.

2. Kanagaraj, J., Chandra Babu, N.K., Alternatives to Salt Curing Techniques-A Review, J Sci Ind Res, 2002, 61, 339-348.

3. Hausam, W., Behaviour of hide during salting and the action on the hide protein, J Am Leather Chem As, 1951, 35, 44.

4. Rajamani, S., Cleaner tanning technologies in the beam house operation, Proceedings of the Symposium on Cleaner Tanning Technologies, UNIDO, September 1998, 2, 21-5.

5. Govindasamy, P., Madhavan, S.D., Revathi, S., Shanmugam, P., Performance Evaluation of Common Effluent Treatment Plant for Tanneries at Pallavaram CETP, J Environ Sci Eng, 2006, 48, 3, 213-220.

6. Vlyssides, A.G., Israilides, C.J., Detoxification of tannery waste liquors with an electrolysis system, Environ Poll, 1997, $97,147$.

7. Sadulla, S., Impact of salinity emanating from tannery environment: Leather processing to the ecosystem, in: Agrobased ecotoxicological preview on anthropogenic activities on ecosystem, Ed. Mwinyikione Mwinyihija, Nova Publishers, New York, 2015, 59-76.

8. Haydar, S., Aziz, J.A., Characterization and treatability studies of tannery wastewater using chemically enhanced primary treatment (CEPT)--a case study of Saddiq Leather Works, J Hazard Mater, 2009, 163, 2-3, 1076-83.

9. Cowan, M.M., Plant products as anti-microbial agents, Clin Microbiol Rev, 1999, 12, 564-82.

10. Dahanukar, S.A., Kulkarni, R.A., Rege, N.N., Pharmacology of Medicinal Plants and Natural Products, Indian J Pharmacol, 2000, 32, 81-118.

11. Vedaraman, N., Bio additive-aided skin preservation - an approach for salinity reduction, Revista de Pielarie Incaltaminte (Leather and Footwear Journal), 2009, 9, 4, 251-257.

12. Vijayalakshmi, K., Judith, R., Suseela, R., Novel plant based formulations for short term preservation of animal 
skin, J Sci Ind Res, 2009, 68, 699-707.

13. Sivabalan, V., Jayanthi, J., A study to reduce salt usage in preservation of skins and hides with alternate use of plant extract, ARPN J of Ag Bio Sci, 2009, 4, 6, 43-48.

14. Iyappan, K., Ponrasu, T., Sangeethapriya, V., Gayathri, V.S., Suguna, L., An eco-friendly method for short term preservation of skins/hides using Semecarpus anacardium nut extract, Environ Sci Pollut Res Int, 2013, 20, 9, 632430.

15. Danish, M., Singh, P., Mishra, G., Srivastava, S., Jha, K.K., Khosa, R.L., Cassia fistula Linn. (Amulthus)- An Important Medicinal Plant: A Review of Its Traditional Uses, Phytochemistry and Pharmacological Properties, J Nat Prod Plant Resour, 2011, 1, 1, 101-118.

16. Tzakou, O., Loukis, A., Said, A., Essential Oil from the Flowers and Leaves of Cassia fistula L., J Essent Oil Res, 2007, 19, 4, 360-361.

17. Mahesh, V.K., Sharma, R., Singh, R.S., Upadhya, S,K., Anthraquinones and kaempferol from Cassia fistula species, J Nat Prod, 1984, 47, 733-751.

18. Morimoto, S., Nonaka, G., Chen, R., Tannins and related compounds, Isolation and structures of novel bi and tri flavonoids from the leaves of Cassia fistula, Chem Pharmacol Bull, 1988, 36, 39-47.

19. Gupta, A.K., Tondon, N., Sharma, M., Quality Standards of Indian Medicinal Plants, Medicinal Plants Unit, Published by Indian Council of Medical Research, 2008, 2, 47-53.

20. Luximon-Ramma, A., Bahorun, T., Soobrattee, M.A., Aruoma, O.I., Antioxidant activities of phenolic, proanthocyanidins, and flavonoid components in extracts of Cassia fistula, J Agri Food Chem, 2002, 50, 5042-5047.

21. Chopra, R.N., Nayar, S.L., Chpora, I.C., Glossary of Indian Medicinal Plants, National Institute of Science Communication and Information Resources, 2006, p. 54.

22. Perumal, R., Ignacimuthu, S., Sen, A., Screening of 34 medicinal plants antibacterial properties, J Ethanopharm, 1998, 62, 173-182.

23. Phongpaichit, S., Pujenjob, N., Rukachaisirikul, V., Ongsakul, M., Antifungal activity from the leaf extract of Cassia fistula, J Sci Technol, 2004, 26, 5, 741-748.

24. Vasudevan, D.T., Dinesh, K., Gopalakrishnan, S., Shekar, S., The potential of aqueous and isolated fraction from the leaves of Cassia fistula as an antibacterial agent, Int J Chem Sci, 2009, 7, 4, 2363-2367.

25. Okwu, D.E., Ekeke, O., Phytochemical screening and mineral composition of chewing sticks in South Eastern Nigeria, Global J Pure Appl Sci, 2003, 9, 235-238.

26. Gutiérrez, R.M., Mitchell, S., Solis, R.V., Psidium guajava: A review of its traditional uses, phytochemistry and pharmacology, JEthnopharm, 2008, 117, 1, 1-27.

27. Trusheva, B., Trunkova, D., Bankova, V., Different extraction methods of biologically active components from propolis: a preliminary study, Chemistry CentralJ, 2007, 7, 1-13.

28. NCCLS, Methods for dilution antimicrobial susceptibility tests for bacteria that grow aerobically - approved standard. 1997. NCCLS document M7-A4. Fourth edition, Approved standard ed., Pennsylvania: NCCLS.

29. Woessner, J.F., Jr., The determination of hydroxyproline in tissue and protein samples containing small proportions of this amino acid, Arch Biochem Biophys, 1961, 93, 440-447.

30. Lowry, O.H., Rosebrough, N.J., Farr, A.L., Randall, R.J., Protein measurement with the folin's phenol reagent, J Biol Chem, 1951, 193, 265-276.

31. Bhalodia, N.R., Shukla, V.J., Antibacterial and antifungal activities from leaf extracts of Cassia fistula L.: An ethnomedicinal plant, J Adv Pharm Technol Res, 2011, 2, 2, 104-109.

32. Biswas, B., Rogers, K., McLaughlin, F., Daniels, D., Yadav, A., Antimicrobial Activities of Leaf Extracts of Guava (Psidium guajava L.) on Two Gram-Negative and Gram-Positive Bacteria, Int J Microbiol, 2013, 74, 61-65.

33. Kanagaraj, J., Chandra Babu, N.K., Sadulla, S., Suseela Rajkumar, G., Visalakshi, V., Chandra Kumar, N., Cleaner 
techniques for the preservation of raw goat skins, J Clean Prod, 2001, 9, 261-268.

34. Springer, H., John Arthur Wilson Memorial Lecture Treatment of Industrial Wastes of the Leather Industry - is it still a Major Problem $\Delta$, J Am Leather Chem As, 1994, 89, 153-185.

35. Islam, B.I., Musa, A.E., Ibrahim, E.H., Salma, A.A.S., Elfaki, B.M., Evaluation and Characterization of Tannery Wastewater, Journal of Forest Products \& Industries, 2014, 3, 141-150.

Article received/Data primirii articolului: 25.05.2016

Accepted/Acceptat la data: 27.06.2016 